Article

\title{
Life Satisfaction, Physical Activity and Quality of Life Associated with the Health of School-Age Adolescents
}

\author{
José D. Urchaga ${ }^{1}\left(\mathbb{D}\right.$, Raquel M. Guevara $^{2, *} \mathbb{D}$, Antonio S. Cabaco ${ }^{3} \mathbb{D}$ and José E. Moral-García ${ }^{2} \mathbb{D}$ \\ 1 Faculty of Communication, Pontifical University of Salamanca, C/Compañía,5, 37002 Salamanca, Spain; \\ jdurchagali@upsa.es \\ 2 Faculty of Education, Pontifical University of Salamanca, C/Compañía,5, 37002 Salamanca, Spain; \\ jemoralga@upsa.es \\ 3 Faculty of Psychology, Pontifical University of Salamanca, C/Compañía,5, 37002 Salamanca, Spain; \\ asanchezca@upsa.es \\ * Correspondence: rmguevarain@upsa.es
}

Received: 1 September 2020; Accepted: 11 November 2020; Published: 14 November 2020

\begin{abstract}
The main purpose of this study is to understand the Quality of Life Associated with Health (QLAH) of a sample of school-age adolescents, and the existing associations between the latter and other variables, such as family life satisfaction, personal life satisfaction (LS), friendships satisfaction, physical activity with family, friends and personal physical activity. The sample consisted of 1226 Spanish school-age adolescents ( $50.9 \%$ boys and $40.1 \%$ girls) with ages between 12 and 16 years old. Several scales that were extracted from the international Health Behaviour in School-aged Children (HBSC) 2016 study, sponsored by the World Health Organization (WHO), were used as working instruments in this piece of research. SPSS (24.0) was the software package used to perform the analyses of descriptive statistics, correlation and multiple regression, whereas AMOS (24.0) was used for structural equations. The results reveal a strong association between the physical activity (PA) students undertake (personal, with their families and friends) and life satisfaction, family life satisfaction and satisfaction with the relationships with friends. Additionally, both constructs (physical activity and satisfaction, understood as an indicator of good health) can predict the respondents' Quality of Life Associated with Health. The variables (QLAH, LS and PA) are interrelated, thus resulting in major practical implications.
\end{abstract}

Keywords: adolescence; life satisfaction; healthy habits; family; peer relationships; school

\section{Introduction}

Adolescence is a particularly relevant stage in the development of individuals, as it is during this time that identity is formed, the individual's socialisation process evolves, with many of the habits that will accompany them throughout their adult age also being acquired at this stage. In recent decades, numerous research studies have focused on this stage as a major development stage [1-5] and have highlighted it as a key time for the adoption of healthy lifestyles, pointing out its importance for building positive family and social relationships that ensure the wellbeing of the individual [6-11]. Additionally, this is a key stage in the sense that it is the time when the lifestyle of individuals begins to form, potentially affecting their health during adulthood [12,13].

Health is broadly understood-integrating the physical, mental and social dimensions of the adolescent-to depend on diverse factors, such as the environment, human biology or the health system [1-5] determining their future physical, mental and social wellbeing [14]. Comparative studies undertaken in various countries maintain this view [15] and allow for the design of preventative policies, which take into account the role of contextual (country) or personal (age or gender) variables [16]. 
One of the greatest benefits of the adoption and consolidation of healthy habits as a mechanism to improve people's health is the practice of physical activity (PA), which has a positive impact on the physical, physiological, psychological and social spheres of life $[17,18]$. Regular practice of PA positively contributes to the improvement of the physical condition (both the cardiorespiratory functions and muscle strength). Vigorous exercise, for example, has been associated with a healthy level of cardiorespiratory fitness [19]. Research indicates that PA is beneficial in reducing the risk of cardiovascular and metabolic disease, reducing body fat, improving bone health and reducing the symptoms of depression $[18,19]$. It also positively affects mental health, as regular practice of PA increases self-esteem, creating positivity in the individual who exercises, whereas a sedentary lifestyle causes depressive moods and health issues [20].

The consolidation of healthy habits, such as the habitual practice of PA is essential at all stages of life as it brings people numerous benefits in the prevention of disease, the adoption of other healthy habits and as a factor protecting against behaviours that pose a risk to health $[21,22]$. A recent research study [23] discovered that the practice of PA has associations with other parameters, such as the reduction of toxic substance consumption or the improvement of nutrition [24].

In Spain, the data extracted from the Health Behaviour in School-aged Children (HBSC) 2016 [25] study reveal that $48.4 \%$ of adolescents takes PA according to the recommendations of the World Health Organization (WHO) [26]. Additionally, the same study shows that boys tend to practice more PA than girls and that their practice decreases with age in both cases [25]. Despite the positive effects of an active life and the importance of practising PA in childhood and adolescence being known to everyone, only a minority of young people comply with the daily recommendations of practicing moderate to vigorous PA for $60 \mathrm{~min}$ [27-35].

School is noted as being a fundamental entity in the promotion of physical/sports activities [36] and it is considered as a major pillar in the establishment of healthy life habits in adolescence [37,38]. It is important to take into account the ratio between physical education lessons and out-of-school recreational activities $[39,40]$ and the need to increase the practice of physical/sports activities outside school during this period of time, as the amount of PA taken in school does not seem to be sufficient [41].

The family can play a complementary role to that of school, as the simultaneous work in both environments makes it easier to promote active and healthy life habits and to create a good motivational ground from the early stages of life that provides benefits to adolescents [42,43]. The influence that those close to the adolescent can have is an important factor in increasing their motivation and their interest towards physically active activities [43]. In line with this, recent research reveals that the practice of PA within the family promotes PA in adolescence [44-51]. The practice of PA by friends also seems to impact on the personal practice of PA [50-53].

In terms of mental health, literature shows that the life satisfaction (LS) adolescents report to have is closely linked to their wellbeing, with this being a subjective indicator [54] arising from the comparison between their personal circumstances and what they believe to be an adequate life standard [55], which also has major implications in the psychological, social and educational functioning of these individuals [56-60].

Numerous research studies prove that adolescents' satisfaction with life is especially related to the experiences the individuals have with their families [8,61], which is the main source of support providing wellbeing to the individuals, together with their friends [62-65]. Other authors [10], confirm a high level of family harmony as being crucial to the development of an adolescent. Aspects such as school satisfaction, health, money and work are also related to the level of life satisfaction in adolescents, where their relationships with friends are an important factor for their psychological development [66,67].

Additionally, several papers take both aspects into account, i.e., PA and LS, and state that there is a close association between them. These studies have found that people whose life habits include PA have a better perception of their health and LS levels [68-71]. Since the 80s, the assessment of Quality of Life Associated with Health (QLAH) has acquired certain importance in research as a 
measurement of health, being understood as a valid construct for the assessment of adolescents' health [72]. This multidimensional construct includes the subjective assessment of social, physical and cognitive functioning, mobility, personal care and emotional wellbeing [73]. In the same way, physical condition associated with health $(\mathrm{PFH})$ is deemed to be one of the factors determining Quality of Life Associated with Health (QLAH) [74,75].

Another important factor to take into account is the measuring instruments employed in this research, as a variety of scales have been used to assess the construct "quality of life in adolescents". In the last fifty years, the most commonly used instrument for data taken from over half a million adolescents interviewed in America and Europe, was PedsQ1 [76], in situations associated with pathologies, whereas KIDSCREEN [77] was used for healthy adolescents. There are also questionnaires on the quality of life of adolescents [78], which are specific for studies associated with their carers or to help assess the efficiency of student programs such as CHQ [79].

Although quality of life, health and practice of PA have been analysed in previous studies, there are not enough studies dealing with the connection between all these variables in school-age adolescents. There is a need to analyse the relationships between the physical, mental and social health of adolescents in order to find out the degree to which the factors under study in these three dimensions can predict the health status of the adolescent (according to their Quality of Life Associated with Health). This research intends to understand the Quality of Life Associated with Health (QLAH) and the relationship existing between this and other variables, such as family life satisfaction, life satisfaction, satisfaction with the relationships with friends, family physical activities, friends' physical activities and personal physical activity. The innovative aspect that the investigation contributes is the study of the aforementioned concepts as a whole, against the other more fragmented or bilateral views contributed by previous research studies.

\section{Materials and Methods}

\subsection{Design and Participants}

The sample was taken in the city of Salamanca, in Spain. A descriptive cross-sectional study was designed with the participation of 16 schools selected by conglomerate stratified random multistage sampling, which provided a representation of the 4 areas of social action of the city and the types of schools (state or semi-state).

The total sample consisted of 1226 Spanish school-aged adolescents (50.9\% boys and $49.1 \%$ girls), enrolled in the 2017/2018 school year and distributed into 2 academic levels: 1st year of Obligatory Secondary Education with 602 participants (331 boys and 271 girls; age: $12.9 \pm 0.57$ years old) and 4th year of Obligatory Secondary Education with 624 participants ( 281 boys and 343 girls; age: $16.09 \pm 0.73$ years old $)$. The sample had a margin error of $2 \%(p=q=0.5$; confidence level $=95 \%)$.

\subsection{Instruments}

A sociodemographic questionnaire and various specific scales, which were validated for the study of the various constructs, were used. All of them are also present in the HBSC study [25]. The following are the instruments employed:

(a) Sociodemographic questionnaire in order to determine sex (male and female) and age in years.

(b) In order to measure the level of personal life satisfaction (PLS), Cantril's scale [80] was used, consisting of only one-item question: "Generally speaking, what do you feel your life is like at present?". A scale of 0 to 10 was used for the answer options, where 0 means "The worst life possible" and 10 means "The best life possible".

(c) Family life satisfaction (FLS) was measured by adapting the Cantril [80] scale and it consisted of only one-item question: "Generally speaking, how satisfied are you with your family relationships?". A scale of 0 to 10 was used for the answer options, where 0 means "My family does not get on at all" and 10 means "My family gets on really well". 
(d) Satisfaction with the relationships with friends (SF) was measured using the following question: "If you were to rate the relationship you have with your friends in general, what score would you give it?" A scale of 0 to 10 was used for the answer options, where 0 means "I have the worst relationship possible with my friends" and 10 means "I have the best relationship possible with my friends".

(e) PA was assessed by means of three specific items extracted from the HBSC (2014) study questionnaire [81]: two questions relating to family, one related with personal physical activity and one with the sports activities undertaken by friends: Family: "How frequently do you and your family usually do one of the following things together? Go out for walks together (FPA-W); Practice sports together" (FPA-S). Both questions had 5 answer options: every day (5), most days (4), approximately once a week (3), less often than once a week (2), never (1). Personal physical activity (PPA): "In the last 7 days, how many days were you physically active for a total of at least $60 \mathrm{~min}$ per day? The answer options offered were from 0 to 7 days. Sports physical activity undertaken by friends (PAF-S): "Most people within my groups of friends practice some sports activity with other people". Four potential answer options were provided (never, rarely, occasionally, often).

(f) The QLAH was assessed using the Kidscreen-10 [77] package, which is a tool that can allocate a global index for emotional wellbeing through 10 items which comprise physical, psychological and social aspects. The students were required to answer whether "in the last week" they felt well and fit, full of energy, sad, lonely, whether they had enough time for themselves, managed to do the things they wanted to do in their leisure time, were treated fairly by their parents, had a good time with their friends, things went well in school or high school, and whether they were able to concentrate or pay attention. The score for each of the items went from 1 to 5 (never, rarely, occasionally, almost always and always).

\subsection{Procedure}

This research study was developed in compliance with the ethical code of the Declaration of Helsinki, revised in 2013, applicable to these types of research studies, but also adapted to the Data Protection Act (Organic Law 15/1999) and under the premises of the Spanish currently effective laws on research with human subjects (Royal Decree 561/1993). The study protocol was approved by the Ethics Committee for Research with Human Subjects of the Pontifical University of Salamanca.

Before the data were collected, the school centres were approached in order to obtain prior permission for the respondents to participate in the study. Parental consent was also sought so that they could be part of the research by explaining to the adolescents that the data would be processed anonymously and voluntarily. Participants did not obtain compensation for their contributions. In order to prevent the respondents' answers from being biased, a coding system was used to guarantee anonymity and confidentiality of the respondents at all times. Questionnaires were completed within the normal school hours at the time allocated to personal tutoring support, by trained interviewers under the supervision of the main researcher. The students answered the questionnaire in approximately ten minutes.

The procedure (Figure 1) complied with the three basic requirements of the International Coordinating Centre of the HBSC study: the students answered the questionnaire by themselves; anonymity of the answers was assured and guaranteed and the questionnaires were administered within the school centre.

The inclusion criteria were: voluntary student participation and provision of parental or legal custodian authorisation. The exclusion criteria for this piece of research were: the provision of inappropriate or incomplete answers to any of the items in the questionnaires, failure to provide parental or legal custodian authorisation, evidence of a pathology that could prevent the child from regularly practicing PA during the time of the study or in the 6 previous months. 


\section{RESEARCHERS RESPONSIBLE FOR CONDUCTING THE INTERVIEWS}

A) Selection of the researchers supervising the interviews
B) Theory and practice training with instruments (interviews)

\section{CONTACT WITH PARENTS/ LEGAL CUSTODIANS AND SCHOOL CENTRE}

A) Information provided to the parents/ legal custodians and the school centre on the research
B) Permission from parents/ legal custodians and the school centre to carry out the research

\section{SURVEY DEVELOPMENT}

A) Completion of the interviews by the students, under the supervision of the researchers
B) Collection of interviews; inclusion and data statistical analysis (SPSS)

Figure 1. Chart on the step-by-step procedure of the survey.

\subsection{Data Analysis}

Data analysis was performed using the SPSS 24.0. and AMOS 24.0 software packages. Descriptive statistics were used in order to understand the distribution; the Pearson correlation index was employed for the study of the bivariate relationships; and multiple regression was used for the prediction of variables QLAH, personal life satisfaction (PLS) and personal physical activity (PPA). The AMOS 24.0 software package allowed for the study of the structural equation modelling adjustments using the Maximum Likelihood method.

\section{Results}

Initially, the predicted correlations were presented in the five research-specific objectives and, subsequently, the result of a model of structural equations.

\subsection{Correlation Analysis}

The correlations obtained amongst the variables being the object of the study (Table 1) prove to all be significant $(p<0.01)$, and to follow the predicted pattern.

In the first place, positive correlations have been identified between the PA practiced with the family, the PA practiced by the adolescent and the PA practiced by their friends. There are very significant correlations $(p<0.001)$ between the personal physical activity (PPA) undertaken and both the sports/physical activity practiced with the family (FPA-S) (0.229) and the sports/physical activity practiced by friends (PAF-S) (0.211).

In line with expectations, in second place there were positive correlations between personal life satisfaction and family life satisfaction (0.528) as well as friendships satisfaction (0.329). There is also a positive correlation between family life satisfaction (FLS) and friendships satisfaction (FS) (0.227).

Family life satisfaction (FLS) is positively correlated with the practice of family physical activity, whether it is a sports activity (FPA-S) (0.287) or walks (FPA-W) (0.361).

In fourth place, QLAH is confirmed to be correlated with the various types of PA (family, personal and friends' activities), as well as LS (with the family, with oneself and with friends). The closest correlations between QLAH and the level of satisfaction are obtained with personal life satisfaction (PLS) (0.585) and family life satisfaction (FLS) (0.496). The closest correlations between QLAH and PA are obtained with family sports/physical activity (FPA-S) (0.314) and personal physical activity (PPA) (0.299). 
Table 1. Summary of the inter-correlations and descriptors for scores in QLAH, FLS, PLS, FS, FPA-W, FPA-S, PPA and PAF-S.

\begin{tabular}{ccccccccc}
\hline & QLAH & FLS & PLS & FS & FPA-S & FPA-W & PPA & PAF-S \\
\hline FLS & $0.496^{* * *}$ & & & & & & & \\
PLS & $0.585^{* * *}$ & $0.528^{* * *}$ & & & & & & \\
FS & $0.322^{* * *}$ & $0.227^{* * *}$ & $0.329^{* * *}$ & & & & & \\
FPA-S & $0.267^{* * *}$ & $0.287^{* * *}$ & $0.257^{* * *}$ & $0.165^{* * *}$ & & & & \\
FPA-W & $0.314^{* * *}$ & $0.361^{* * *}$ & $0.295^{* * *}$ & $0.086^{* *}$ & $0.456^{* * *}$ & & & \\
PPA & $0.299^{* * *}$ & $0.136^{* * *}$ & $0.169^{* * *}$ & $0.182^{* * *}$ & $0.229^{* * *}$ & $0.090^{* *}$ & & \\
PAF-S & $0.209^{* * *}$ & $0.167^{* * *}$ & $0.108^{* * *}$ & $0.089^{* *}$ & $0.160^{* * *}$ & $0.104^{* * *}$ & $0.211^{* * *}$ & \\
M & 37.9 & 8.30 & 7.79 & 8.83 & 2.10 & 2.62 & 4.38 & 2.60 \\
SD & 6.07 & 1.89 & 1.65 & 1.28 & 1.197 & 1.14 & 1.96 & 0.592 \\
Skewness & -0.48 & -1.49 & -0.92 & -1.87 & 0.82 & 0.20 & -0.22 & -1.19 \\
Kurtosis & 0.21 & 2.67 & 1.29 & 5.70 & -0.37 & -0.69 & -0.89 & 0.41 \\
\hline
\end{tabular}

Note: QLAH: Quality of Life Associated with Health; FLS: Family Life Satisfaction; PLS: Personal Life Satisfaction; FS: Friendships Satisfaction; FPA-S: Family Physical Activity: Sports; FPA-W: Family Physical Activity: Walks; PPA: Personal Physical Activity (last week, 60 min./day); PAF-S: Sports/Physical Activity Practiced by Friends); M: mean; SD: standard deviation. ${ }^{* *} p<0.01 ;{ }^{* * *} p<0.001$.

Multiple regression. The relevant multiple regression analysis was performed via the "step by step" procedure for the prediction of the QLAH, PLS and PPA variables, with a 0.05 probability entry criterion and 0.10 probability removal criterion. The results (Table 2) reveal that QLAH is the most predictable variable $\left(R^{2}=0.451\right)$, with the satisfaction parameters under consideration being very relevant (family, friendships and personal life satisfaction), as well as various aspects of physical activity (personal, friends and family walks). PLS is the second most predictable variable $\left(R^{2}=0.436\right)$ and for this prediction QLAH, FLS, FS and FPA-W are relevant. And lastly, the prediction of PPA is very low $\left(R^{2}=0.142\right)$, which includes QLAH, the three PA variables (FPA-S, FPA-W and PAF) and FS.

Table 2. Multiple regression models for QLAH, PLS and PPA: last step.

\begin{tabular}{|c|c|c|c|c|c|c|c|c|c|c|c|}
\hline \multirow{2}{*}{$\begin{array}{l}\text { Dependent } \\
\text { Variable }\end{array}$} & \multirow[b]{2}{*}{ Step } & \multirow[b]{2}{*}{ Model } & \multicolumn{5}{|c|}{ Coefficients } & \multicolumn{2}{|c|}{ Correlations } & \multicolumn{2}{|c|}{ Collinearity } \\
\hline & & & $B^{\text {d }}$ & $S E^{\mathrm{d}}$ & $B^{\mathrm{e}}$ & $t$ & $p$ & Zero-Order & Partial & Tolerar & $\operatorname{eVIF}^{f}$ \\
\hline \multirow[t]{8}{*}{$\mathrm{QLAH}^{\mathrm{a}}$} & 6 & (Constant) & 11.47 & 1.080 & & 10.61 & $<0.001$ & & & & \\
\hline & & PLS & 1.40 & 0.096 & 0.379 & 14.51 & $<0.001$ & 0.585 & 0.384 & 0.659 & 1.52 \\
\hline & & FLS & 0.648 & 0.084 & 0.201 & 7.73 & $<0.001$ & 0.496 & 0.216 & 0.663 & 1.51 \\
\hline & & PPA & 0.504 & 0.069 & 0.163 & 7.34 & $<0.001$ & 0.299 & 0.206 & 0.917 & 1.09 \\
\hline & & FS & 0.508 & 0.108 & 0.107 & 4.71 & $<0.001$ & 0.322 & 0.134 & 0.871 & 1.15 \\
\hline & & FPA-W & 0.518 & 0.122 & 0.097 & 4.23 & $<0.001$ & 0.314 & 0.120 & 0.851 & 1.18 \\
\hline & & PAF-S & 0.831 & 0.225 & 0.081 & 3.70 & $<0.001$ & 0.209 & 0.105 & 0.934 & 1.07 \\
\hline & \multicolumn{11}{|c|}{$\begin{array}{c}\text { Model Summary: } R=0.672 ; R^{2}=0.451 ; \text { adj } R^{2}=0.449 ; S E E^{g}=4.50 \\
\text { ANOVA: } F=167.7 . ; p<0.001\end{array}$} \\
\hline \multirow[t]{6}{*}{$\mathrm{PLS}^{\mathrm{b}}$} & 4 & (Constant) & 0.012 & 0.292 & & 0.04 & 0.968 & & & & \\
\hline & & QLAH & 0.103 & 0.007 & 0.380 & 14.65 & $<0.001$ & 0.585 & 0.387 & 0.687 & 1.46 \\
\hline & & FLS & 0.251 & 0.022 & 0.287 & 11.20 & $<0.001$ & 0.528 & 0.305 & 0.701 & 1.43 \\
\hline & & FS & 0.175 & 0.029 & 0.136 & 5.97 & $<0.001$ & 0.329 & 0.168 & 0.889 & 1.13 \\
\hline & & FPA-W & 0.088 & 0.034 & 0.061 & 2.60 & 0.010 & 0.295 & 0.074 & 0.844 & 1.18 \\
\hline & \multicolumn{11}{|c|}{$\begin{array}{c}\text { Model Summary: } R=0.661 ; R^{2}=0.436 ; \text { adj } R^{2}=0.435 ; \text { SEE }{ }^{g}=1.24 \\
\text { ANOVA: } F=236.6 . ; p<0.001\end{array}$} \\
\hline
\end{tabular}


Table 2. Cont.

\begin{tabular}{|c|c|c|c|c|c|c|c|c|c|c|c|}
\hline \multirow{2}{*}{$\begin{array}{l}\text { Dependent } \\
\text { Variable }\end{array}$} & \multirow[b]{2}{*}{ Step } & \multirow[b]{2}{*}{ Model } & \multicolumn{5}{|c|}{ Coefficients } & \multicolumn{2}{|c|}{ Correlations } & \multicolumn{2}{|c|}{ Collinearity } \\
\hline & & & $B^{\mathrm{d}}$ & $S E^{\mathrm{d}}$ & $B^{\mathbf{e}}$ & $t$ & $p$ & Zero-Order & Partial & Tolera & VIF $^{f}$ \\
\hline \multirow[t]{7}{*}{$\mathrm{PPA}^{\mathrm{c}}$} & 5 & (Constant) & -0.812 & 0.455 & & -1.79 & 0.074 & & & & \\
\hline & & QLAH & 0.073 & 0.010 & 0.225 & 7.51 & $<0.001$ & 0.299 & 0.210 & 0.783 & 1.28 \\
\hline & & FPA-S & 0.279 & 0.050 & 0.171 & 5.62 & $<0.001$ & 0.229 & 0.159 & 0.759 & 1.32 \\
\hline & & PAF-S & 0.457 & 0.090 & 0.138 & 5.07 & $<0.001$ & 0.211 & 0.144 & 0.944 & 1.06 \\
\hline & & FS & 0.117 & 0.043 & 0.076 & 2.70 & 0.007 & 0.182 & 0.077 & 0.886 & 1.13 \\
\hline & & FPA-W & -0.137 & 0.053 & -0.079 & -2.60 & 0.010 & 0.090 & -0.074 & 0.750 & 1.33 \\
\hline & \multicolumn{11}{|c|}{$\begin{array}{c}\text { Model Summary: } R=0.377 ; R^{2}=0.142 ; \text { adj } R^{2}=0.139 ; \text { SEE }{ }^{g}=1.82 \\
\text { ANOVA: } F=40.56 . ; p<0.001\end{array}$} \\
\hline
\end{tabular}

a. Excluded variable: FPA-S; b. Excluded variables: FPA-S, PAF-S and PPA; c. Excluded variables: FLS and PLS;

d. Unstandardized; e. Standardized; f. VIF = Variance inflation factor; g. SEE = Standard error of estimate.

\subsection{Structural Equation Model}

Based on the above results, a model of association amongst the variables was sought, taking QLAH as a dependent variable and to include in the model both satisfaction variables and physical activity variables. Prior to the PathAnalysis, multivariate normality was checked [82] which can be admitted for large samples if the variables take asymmetry values below 3 and kurtosis values of 10 (Table 2). The working methodology consisted of adding variables and their associations for the purposes of predicting QLAH, in a way that a theoretically interpretable model could be obtained and the adjustment indexes could be acceptable.

The model obtained (Figure 2) revealed an RMSEA (Root Mean Square Error of Approximation) of $0.06(\mathrm{CI} 90 \%=0.019,0.113)$ with a PClose of 0.282 , which indicates an adequate model adjustment. The incremental adjustment indexes reveal optimal adjustment (NFI, normal fit index $=0.996$; FRI, flexibility-rigidity index $=0.959$; IFI, incremental fit index $=0.997$; TLI, Tucker Lewis index $=0.966$; CFI, Bentler comparative fit index $=0.997)[82,83]$.

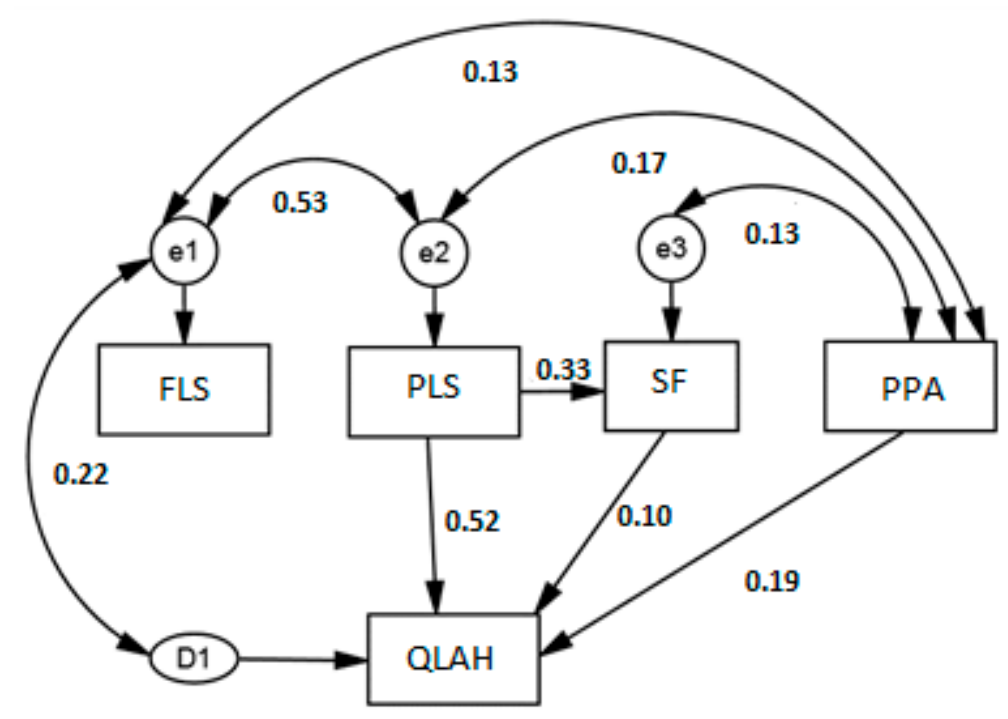

Figure 2. Structural equation modelling for the prediction of QLAH based on FLS, PLS, FS and PPA. Estimates for the standardised maximum likelihood parameters. All the coefficients are significant for $p<0.001$.

The model explains $38.4 \%$ of the variance of QLAH. Variables PLS (0.519) and PPA (0.191) are the ones contributing most to explain QLAH directly, followed by FS (.104). Additionally, the indirect effect of PLS (0.034) on QLAH through FS should be taken into account. 
The model establishes that there are correlations between PPA and the various LS dimensions under assessment (personal, family and friends), as well as between PLS and FLS and FS and the last two with QLAH.

\section{Discussion}

The results of this research study are in line with other Spanish research on physical activity, with personal physical activity being associated with family physical activity $[44,45]$. Thus, adolescents who state they walk in the company of their parents and that they practice physical activity with them on a regular basis reveal better levels of physical activity and, in turn, according to the data obtained, better family life satisfaction. It is therefore essential for the family to support children in the practice of PA and even for them to practice it together [46-48], since such support can be determining in the consolidation of healthy habits, even in adulthood [49]. Various research studies have confirmed that adolescence is a key stage for the consolidation of lifestyle and practice of PA on a regular basis [11,18].

The results are also in line with other studies which prove an association between the personal physical activity and the fact that friends practice physical activity too [62-66]. In fact, the friendships social environment has an impact on the practice of PA; thus, adolescents who are friendly with physically active individuals are more likely to move away from sedentary habits and to remain more physically active [51]. This influence of friends on the promotion of healthy lifestyles can exist from childhood to late adolescence [63].

On the other hand, the LS of the adolescents being interviewed was closely associated with their family life satisfaction and their friendships satisfaction $[8,10,61]$. A close bond with their families and positive social relationships undoubtedly have an impact on the health of adolescents; and therefore it is proven as essential to promote measures to guarantee such healthy relationships, as they help improve LS, PA and QLAH at this stage of development. In this sense, life satisfaction is also reinforced when adolescents share their problems or concerns with their parents and friends [63]. Therefore, subjective wellbeing is positively associated with the interactions between family members and friends, for example, when they share daily life activities [64].

Adolescents who enjoy a better QLAH reveal greater perceived support in the adoption of healthy habits, such as the practice of PA, by their parents and friends [65]. The above-mentioned empiric evidence has an impact on the improvement of the physical condition and on the prevention of cardiovascular disease [11], contributing to improved psychosocial health status [67], socialisation and even academic performance [58-60].

In today's society, and more particularly during a health pandemic (COVID-19), it is especially relevant to promote the wellbeing of people of all ages, ensuring they enjoy a healthy lifestyle and environment as the means to sustainable development. The factors determining and influencing the health of people are numerous and these have an impact on their development. Amongst them, physical condition plays a particularly relevant role [24,74]. For example, promoting the regular practice of physical exercise is essential to help adopt an active and healthy lifestyle at certain stages of life [31]. In this sense, children and adolescents are recommended to practice moderate to vigorous physical activity for over $60 \mathrm{~min}$ every day [32] in order to ensure reinforced wellbeing from an early stage of life [33,34], as this habit can be extended to adulthood [24]. In spite of this, the practice of physical activity remains below the recommended levels [35]. In light of this, it becomes necessary to create an environment that promotes healthy lifestyles, where the structure and design of the cities allow for the sustainable development [16] of their inhabitants, as well as for the educational institutions and the local communities to make an effort to promote the adoption of habits that contribute to good physical, mental and social health.

A limitation of this piece of research is that with the purpose of comparing its findings against the HBSC internartional study, this study used single-item instruments (such as the Cantril Scale) in order to measure the level of personal life satisfaction (PLS), family life satisfaction (FLS) and satisfaction 
with the relationships with friends (SF). We believe for further research work it is important to use instruments with more items.

\section{Conclusions}

This study reveals that LS in the adolescent and PA are directly connected with positive relationships with their families and friends, as well as the physical activity the family and friends practice. QLAH can be predicted to a great extent from the satisfaction of the adolescent (with life, with their family life and with their friendships) and from their practice of PA (as well as that of the family and friends). Therefore, the study reveals there is an interrelationship between LS, QLAH and PA, which are the three dimensions of an integral concept of health.

However, the results of this study have limitations, including the use of a cross-sectional design, as well as the critical considerations that these types of studies receive, as they follow self-reporting methods and therefore do not consider subjective factors [84]. On the other hand, one strength that must be highlighted is the sample volume and type, as well as the inclusion of variables relating to family and friends.

From an applied point of view, the evidence of an existing association amongst LS, QLAH and the practice of PA for adolescents' health and their healthy habits implies that it is important to promote positive relationships in the family and with friends [58,65,67]. It is therefore essential to develop strategies to promote healthy lifestyles, involving various sectors, such as the educational, social, family and the media sectors. This is a strategy that prevents the issues identified in later stages of development such as, for example, in university students, where the time spent using social media has been found to have, amongst other effects, a reduction in the practice of physical activity and a poorer quality of life [75]. Therefore, the study of groups of populations performed by life stages, in spite of being cross-sectional, as is the case with this study, provides the possibility of establishing prospective views that can be the grounds for disease prevention and health-promotion programs.

Author Contributions: Conceptualisation, R.M.G., A.S.C. and J.E.M.-G.; methodology J.D.U. and J.E.M.-G.; formal analysis, J.D.U.; investigation, R.M.G.; data curation, J.D.U.; writing-original draft preparation, J.D.U., R.M.G., A.S.C. and J.E.M.-G.; writing-review and editing, R.M.G. and J.E.M.-G.; visualisation, J.D.U. and A.S.C.; supervision, J.D.U. and R.M.G.; project administration, R.M.G.; funding acquisition, J.D.U., R.M.G., A.S.C. and J.E.M.-G. All authors have read and agreed to the published version of the manuscript.

Funding: This research received no external funding.

Conflicts of Interest: The authors declare no conflict of interest.

\section{References}

1. Erikson, E.H. Sociedad y Adolescencia; Siglo XXI Editores: Mexico City, Mexico, 1972.

2. Serapio, A. Realidad psicosocial: La adolescencia actual y su temprano comienzo. Rev. Estud. Juv. 2006, 73, 11-23.

3. Oliva, A.; Pertegal, M.A. Desarrollo positivo adolescente. In El Desarrollo Positivo Adolescente. Un Nuevo Paradigma Para la Investigación y la Intervención; Editorial Síntesis: Madrid, Spain, 2015; pp. 19-40.

4. Oliva, A.; Ríos, M.; Antolín-Suárez, L.; Parra, A.; Hernando, A.; Pertegal, A. Más allá del déficit: Construyendo un modelo de desarrollo positivo adolescente. Infancia y Aprendizaje. Infanc. Aprendiz. 2010, 33, $223-234$. [CrossRef]

5. Brink, A.J.; Wissing, M.P. A model for a positive youth development intervention. J. Child Adolesc. Ment. Health 2012, 24, 1-13. [CrossRef] [PubMed]

6. Ingelmo, R.M.G.; Litago, J.D.U. Life satisfaction and family relationships and with peers in adolescence. Cauriensia 2018, 13, 243-258.

7. Martínez-Hernáez, Á.; Marí-Klose, M.; Julià, A.; Escapa, S.; Marí-Klose, P.; DiGiacomo, S. Adolescent daily smoking, negative mood-states and the role of family communication. Gac. Sanit. 2012, 26, 421-428. [CrossRef]

8. Muratori, M.; Zubieta, E.; Ubillos, S.; González, J.L.; Bobowik, M. Happiness and psychological well-being: A comparative study between Argentina and Spain. Psykhe 2015, 24. [CrossRef] 
9. Rasmussen, M.; Laumann, K. The role of exercise during adolescence on adult happiness and mood. Leis. Stud. 2014, 33, 341-356. [CrossRef]

10. Li, L.; Bai, L.; Zhang, X.; Chen, Y. Family Functioning during Adolescence: The Roles of Paternal and Maternal Emotion Dysregulation and Parent-Adolescent Relationships. J. Child Fam. Stud. 2018, 27, 1311-1323. [CrossRef]

11. Rosa Guillamon, A.; Garcia Canto, E.; Rodríguez García, P.L.; Pérez Soto, J.J.; Tárraga Marcos, M.L.; Tárraga López, P.J. Physical activity, physical fitness and quality of diet in schoolchildren from 8 to 12 years. Nutr. Hosp. 2017, 34, 1292-1298. [CrossRef]

12. Eaton, D.K.; Kann, L.; Kinchen, S.; Shanklin, S.; Flint, K.H.; Hawkins, J.; Harris, W.A.; Lowry, R.; McManus, T.; Chyen, D.; et al. Youth risk behavior surveillance-United States, 2011. Morb. Mortal. Wkly. Report. Surveill. Summ. 2012, 61, 1-162.

13. Duke, N.N.; Borowsky, I.W. Health Status of Adolescents Reporting Experiences of Adversity. Glob. Pediatr. Health 2018, 5. [CrossRef] [PubMed]

14. Lalonde, M. A New Perspective on the Health of Canadians; A Working Document; Government of Canada: Ottawa, ON, Canada, 1974.

15. Guedes, D.P.; Villagra Astudillo,H.A.; Moya Morales, J.M.; del Campo Vecino, J.; Pires Júnior, R. Health-related quality of life in Latin American adolescents. Rev. Panam. Salud Publica 2014, 35, 46-52. [PubMed]

16. Fathi, S.; Sajadzadeh, H.; Sheshkal, F.M.; Aram, F.; Pinter, G.; Felde, I.; Mosavi, A. The role of urban morphology design on enhancing physical activity and public health. Int. J. Environ. Res. Public Health 2020, 17, 2359. [CrossRef] [PubMed]

17. Thompson, P.D.; Arena, R.; Riebe, D.; Pescatello, L.S. ACSM's new preparticipation health screening recommendations from ACSM's guidelines for exercise testing and prescription, ninth edition. Curr. Sports Med. Rep. 2013, 12, 215-217. [CrossRef]

18. Guevara, R.M.; Urchaga, J.D.; Cabaco, A.S.; Moral-García, J.E. The Quality of Breakfast and Healthy Diet in School-aged Adolescents and Their Association with BMI, Weight Loss Diets and the Practice of Physical Activity. Nutrients 2020, 12, 2294. [CrossRef]

19. Ávila-García, M.; Baena-Ogalla, N.; Huertas-Delgado, F.J.; Tercedor, P.; Villa-González, E. The relationship between physical activity levels, cardiorespiratory fitness and academic achievement school-age children from southern Spain. Sustainability 2020, 12, 3459. [CrossRef]

20. Varo Cenarruzabeitia, J.J.; Martínez Hernández, J.A.; Martínez-González, M.A. Benefits of physical activity and harms of inactivity. Med. Clin. 2003, 121, 665-672.

21. Malta, D.C.; Oliveira-Campos, M.; do Prado, R.R.; Andrade, S.S.C.; de Mello, F.C.M.; Dias, A.J.R.; Bomtempo, D.B. Psychoactive substance use, family context and mental health among Brazilian adolescents, national adolescent school-based health survey (PeNSE 2012) [Uso de substâncias psicoativas, contexto familiar e saúde mental em adolescentes Brasileiros, Pesquisa n]. Rev. Bras. Epidemiol. 2014, 17, 46-61. [CrossRef]

22. Hallingberg, B.; Moore, S.; Morgan, J.; Bowen, K.; Vangoozen, S.H.M. Adolescent male hazardous drinking and participation in organised activities: Involvement in team sports is associated with less hazardous drinking in young offenders. Crim. Behav. Ment. Health 2015, 25, 28-41. [CrossRef]

23. Moral García, J.E.; Agraso López, A.D.; Pérez Soto, J.J.; Rosa Guillamón, A.; Tárraga Marcos, M.L.; García Cantó, E.; Tárraga López, P.J. Phisical activity practice according to adherence to the Mediterranean diet, alcohol consumption and motivation in adolescents. Nutr. Hosp. 2019, 36, 420-427. [CrossRef]

24. Casas, A.G.; Guillamon, A.R.; Garcia-Cantò, E.; Rodrìguez Garcìa, P.L.; Pèrez-Soto, J.J.; Marcos, L.T.; Lòpez, P.T. Estado nutricional y calidad de vida relacionada con la salud en escolares del sureste español. Nutr. Hosp. 2015, 31, 737-743. [CrossRef]

25. Moreno, C.; Ramos, P.; Rivera, F.; Jiménez, A.; García, I.; Sánchez, I.; Moreno, C.; Paniagua, C.; Villafuerte, A.; Morgan, A. Informe Técnico de los Resultados Obtenidos por el Estudio Health Behaviour in School-Aged Children 2014 en España; Ministerio de Sanidad, Servicios Sociales e Igualdad: Madrid, Spain, 2016.

26. Word Health Organization. Global Recommendations on Physical Activity for Health; World Health Organization: Geneva, Switzerland, 2010. 
27. Thivel, D.; Tremblay, M.S.; Katzmarzyk, P.T.; Fogelholm, M.; Hu, G.; Maher, C.; Maia, J.; Olds, T.; Sarmiento, O.L.; Standage, M.; et al. Associations between meeting combinations of 24-hour movement recommendations and dietary patterns of children: A 12-country study. Prev. Med. 2019, 118, 159-165. [CrossRef] [PubMed]

28. Ramos, P.; Jiménez-Iglesias, A.; Rivera, F.; Moreno, C. Physical activity trends in spanish adolescents [Evolución de la práctica de la actividad física en los adolescentes españoles]. Rev. Int. Med. Cienc. Act. Fis. Deport. 2016, 16, 335-353. [CrossRef]

29. Kalman, M.; Inchley, J.; Sigmundova, D.; Iannotti, R.J.; Tynjälä, J.A.; Hamrik, Z.; Haug, E.; Bucksch, J. Secular trends in moderate-to-vigorous physical activity in 32 countries from 2002 to 2010: A cross-national perspective. Eur. J. Public Health 2015, 25, 37-40. [CrossRef]

30. Hallal, P.C.; Andersen, L.B.; Bull, F.C.; Guthold, R.; Haskell, W.; Ekelund, U.; Alkandari, J.R.; Bauman, A.E.; Blair, S.N.; Brownson, R.C.; et al. Global physical activity levels: Surveillance progress, pitfalls, and prospects. Lancet 2012, 380, 247-257. [CrossRef]

31. Rodríguez, M.Á.; Crespo, I.; Olmedillas, H. Exercising in times of COVID-19: What do experts recommend doing within four walls? Rev. Española Cardiol. 2020, 73, 527-529. [CrossRef]

32. Piercy, K.L.; Troiano, R.P.; Ballard, R.M.; Carlson, S.A.; Fulton, J.E.; Galuska, D.A.; George, S.M.; Olson, R.D. The Physical Activity Guidelines for Americans. JAMA 2018, 320, 2020-2028. [CrossRef]

33. Caldwell, H.A.T.; Di Cristofaro, N.A.; Cairney, J.; Bray, S.R.; Macdonald, M.J.; Timmons, B.W. Physical literacy, physical activity, and health indicators in school-age children. Int. J. Environ. Res. Public Health 2020, 17, 5367. [CrossRef]

34. Wilson, B.; Barnett, L. Physical activity interventions to improve the health of children and adolescents in out of home care-A systematic review of the literature. Child. Youth Serv. Rev. 2020, 110, 104765. [CrossRef]

35. Guthold, R.; Stevens, G.A.; Riley, L.M.; Bull, F.C. Global trends in insufficient physical activity among adolescents: A pooled analysis of 298 population-based surveys with 1.6 million participants. Lancet Child Adolesc. Health 2020, 4, 23-35. [CrossRef]

36. Rodríguez, A.N.; Romance García, Á.R.; Chinchilla Minguet, J.L. Learning environments as an active methodology to promote physical activity in Early Childhood Education. A case study [Los ambientes de aprendizaje como metodología activa promotora de la actividad física en Educación Infantil. Un estudio de caso]. Retos 2020, 37, 498-504.

37. Pérez-López, I.J.; Delgado, M. Mejora de los conocimientos, procedimientos y actitudes del alumnado de secundaria tras un programa de intervención en educación física para la salud. Eur. J. Hum. Mov. 2007, $18,61-77$.

38. Torres, J.; Contreras, S.; Lippi, L.; Huaiquimilla, M.; Leal, R. Hábitos de vida saludable como indicador de desarrollo personal y social: Discursos y prácticas en escuelas. Calid. Educ. 2019, 50, 357. [CrossRef]

39. Arundell, L.; Ridgers, N.D.; Veitch, J.; Salmon, J.; Hinkley, T.; Timperio, A. 5-year changes in afterschool physical activity and sedentary behavior. Am. J. Prev. Med. 2013, 44, 605-611. [CrossRef] [PubMed]

40. Arundell, L.; Fletcher, E.; Salmon, J.; Veitch, J.; Hinkley, T. A systematic review of the prevalence of sedentary behavior during the after-school period among children aged 5-18 years. Int. J. Behav. Nutr. Phys. Act. 2016, 13, 93. [CrossRef] [PubMed]

41. Soto, J.J.P.; Cantó, E.G.; Guillamón, A.R.; García, P.L.R.; García, J.E.M.; García, S.L. Relationship between intention to be physically active and after-school physical activity [Relación entre la intención de ser activo y la actividad física extraescolar]. Rev. Psicol. 2019, 37, 389-405. [CrossRef]

42. Trigueros, R.; Aguilar-Parra, J.M.; Cangas, A.J.; Fernández-Batanero, J.M.; Álvarez, J.F. The Influence of the Social Context on Motivation towards the Practice of Physical Activity and the Intention to be Physically Active. Int. J. Environ. Res. Public Health 2019, 16, 4212. [CrossRef]

43. Hagger, M.; Chatzisarantis, N.L.D.; Hein, V.; Soós, I.; Karsai, I.; Lintunen, T.; Leemans, S. Teacher, peer and parent autonomy support in physical education and leisure-time physical activity: A trans-contextual model of motivation in four nations. Psychol. Health 2009, 24, 689-711. [CrossRef]

44. Marques, A.; Valeiro, M.G.; Martins, J.; Fernndez-Villarino, M.A.; Da Costa, F.C. Relationship between physical activity of adolescents and that of mothers/parents [Relación entre la actividad física de los adolescentes y la de madres/padres]. Rev. Psicol. Deport. 2017, 26, 145-155. 
45. Amado, D.; Sánchez-Oliva, D.; González-Ponce, I.; Pulido-González, J.J.; Sánchez-Miguel, P.A. Incidence of Parental Support and Pressure on Their Children's Motivational Processes towards Sport Practice Regarding Gender. PLoS ONE 2015, 10, e0128015. [CrossRef]

46. Brand, C.; Reuter, C.P.; Dias, A.F.; Mota, J.; Duncan, M.; Gaya, A.R.; Reis, L.N.; Renner, J.D.P.; Villa-González, E. Like mother, like son: Physical activity, commuting, and associated demographic factors. Sustainability 2020, 12, 5631. [CrossRef]

47. Bauer, K.W.; Nelson, M.C.; Boutelle, K.N.; Neumark-Sztainer, D. Parental influences on adolescents' physical activity and sedentary behavior: Longitudinal findings from Project EAT-II. Int. J. Behav. Nutr. Phys. Act. 2008, 5, 12. [CrossRef]

48. Ruiz-Ariza, A.; De La Torre-Cruz, M.J.; Suárez-Manzano, S.; Martínez-López, E.J. Support towards physical activity and academic performance regardless of parental socio-educational status|Apoyo hacia la actividad física y rendimiento académico independientemente del estatus socioeducativo parental. Retos 2019, 35, 208-212. [CrossRef]

49. Kwon, S.; Janz, K.F.; Letuchy, E.M.; Burns, T.L.; Levy, S.M. Parental characteristic patterns associated with maintaining healthy physical activity behavior during childhood and adolescence. Int. J. Behav. Nutr. Phys. Act. 2016, 13. [CrossRef] [PubMed]

50. Garcia, J.M.; Sirard, J.R.; Deutsch, N.L.; Weltman, A. The influence of friends and psychosocial factors on physical activity and screen time behavior in adolescents: A mixed-methods analysis. J. Behav. Med. 2016, 39, 610-623. [CrossRef] [PubMed]

51. Garcia, J.M.; Sirard, J.R.; Whaley, D.E.; Rice, D.J.; Baker, K.; Weltman, A. The Influence of Friends and Psychosocial Factors on Physical Activity and Screen Time in Normal and Overweight Adolescents: A Mixed-Methods Analysis. Am. J. Health Promot. 2019, 33, 97-106. [CrossRef]

52. Marks, J.; De La Haye, K.; Barnett, L.M.; Allender, S. Friendship network characteristics are associated with physical activity and sedentary behavior in early adolescence. PLOS ONE 2015, 10. [CrossRef]

53. Edwards, M.J.; Jago, R.; Sebire, S.J.; Kesten, J.M.; Pool, L.; Thompson, J.L. The influence of friends and siblings on the physical activity and screen viewing behaviours of children aged 5-6 years: A qualitative analysis of parent interviews. BMJ Open 2015, 5, 1-7. [CrossRef]

54. Huebner, E.S.; Suldo, S.M.; Smith, L.C.; McKnight, C.G. Life satisfaction in children and youth: Empirical foundations and implications for school psychologists. Psychol. Sch. 2004, 41, 81-93. [CrossRef]

55. Diener, E.; Emmons, R.A.; Larsem, R.J.; Griffin, S. The Satisfaction With Life Scale. J. Pers. Assess. 1985, 49, 71-75. [CrossRef]

56. Chavarría, M.P.; Barra, E. Satisfacción vital en adolescentes: Relación con la autoeficacia y el apoyo social percibido. Ter. Psicológica 2014, 32, 41-46. [CrossRef]

57. Amas, M.; López, A.; Cabaco, A.S. Fiabilidad y validez del “Purpose in life” (PIL) en una muestra clínica. Eur. J. Health Res. 2018, 4, 43-51.

58. Ahumada-Padilla, E.; Del Pino, L.V.; Bustamante-Ara, N. Relationship between physical fitness and academic achievement in chilean schoolchildren of 8th grade. Rev. Chil. Pediatr. 2020, 91, 58-67. [CrossRef] [PubMed]

59. Chaddock-Heyman, L.; Erickson, K.I.; Voss, M.W.; Knecht, A.M.; Pontifex, M.B.; Castelli, D.M.; Hillman, C.H.; Kramer, A.F. The effects of physical activity on functional MRI activation associated with cognitive control in children: A randomized controlled intervention. Front. Hum. Neurosci. 2013, 7, 1-13. [CrossRef] [PubMed]

60. López De Los Mozos Huertas, J. Physical condition and academic performance |Condición física y rendimiento académico. J. Sport Health Res. 2018, 10, 349-360.

61. Acevedo, K.E.; Alfonso, M.L.; Arévalo, N.A.; Arias, D.; Jared, H.; Betancur, J.S.; Cadena, E. Identificación de la salud mental en adolescentes y su relación con la familia. Cart. Comunitaria 2018, 6, 149.

62. Chu, P.S.; Saucier, D.A.; Hafner, E. Meta-analysis of the relationships between social support and well-being in children and adolescents. J. Soc. Clin. Psychol. 2010, 29, 624-645. [CrossRef]

63. Martins, J.; Rodrigues, A.; Marques, A.; Cale, L.; da Costa, F. Adolescents' Experiences and Perspectives on Physical Activity and Friend Influences Over Time. Res. Q. Exerc. Sport 2020. [CrossRef]

64. Savahl, S.; Adams, S.; Florence, M.; Casas, F.; Mpilo, M.; Isobell, D.; Manuel, D. The Relation between children's Participation in Daily Activities, Their Engagement with Family and Friends, and Subjective Well-Being. Child Indic. Res. 2020, 13, 1283-1312. [CrossRef] 
65. Moral-García, J.E.; Urchaga-Litago, J.D.; Ramos-Morcillo, A.J.; Maneiro, R. Relationship of parental support on healthy habits, school motivations and academic performance in adolescents. Int. J. Environ. Res. Public Health 2020, 17, 882. [CrossRef]

66. Alfaro, J.; Guzmán, J.; Reyes, F.; García, C.; Varela, J.; Sirlopú, D. Satisfacción global con la vida y satisfacción escolar en estudiantes chilenos. Rev. Psykhe 2016, 25, 1-14. [CrossRef]

67. Sánchez-Miguel, P.A.; González, J.J.P.; Alonso, D.A.; Marcos, F.M.L.; Sánchez-Oliva, D.; Ponce, I.G. Profiles of parental behavior in sport and its relationship with their children' motivational processes. Motricidade 2015, 11, 129-142. [CrossRef]

68. Videra-Garcia, A.; Reigal-Garrido, R.E. Autoconcepto físico, percepción de salud y satisfacción vital en una muestra de adolescentes. Ann. Psicol. 2013, 29, 141-147. [CrossRef]

69. Fraguela-Vale, R.; Varela-Garrote, L.; Sanz-Arazuri, E. Ocio deportivo, imagen corporal y satisfacción vital en jóvenes españoles. Rev. Psicol. Deport. 2017, 13, 263-272.

70. Goñi, E.; Infante, G. Actividad físico-deportiva, autoconcepto físico y satisfacción con la vida. Eur. J. Educ. Psychol. 2010, 3, 199-208. [CrossRef]

71. Gil de Montes, L.; Arruza, J.A.; Arribas, S.; Verde, A.; Ortiz, G.; Irazusta, S. El papel de los otros significativos en la motivación intrínseca de deportistas. Rev. Iberoam. Psicol. Ejerc. Deporte 2007, 2, 97-112.

72. Roizen, M.; Urzúa, A. Calidad de vida y salud en la infancia y la adolescencia. Rev. Típica 2010, 6, $244-249$.

73. Shumaker, S.; Berson, R. The International Assessment of Health-Related Quality of Life: A Theoretical Perspective; Rapid Communications: Oxford, UK, 1995.

74. Nieto-López, L.; García-Cantó, E.; Rosa-Guillamón, A. Relationship between fitness level and perceived health-related quality of life in adolescents from southeast Spain. Rev. Fac. Med. 2020, 68. [CrossRef]

75. Hanna, M.; Ocampo, M.; Janna, N.; Gutiérrez, C.; Torreglosa, L. Redes sociales y calidad de vida relacionada con la salud en estudiantes universitarios. Rev. Cuid. 2020, 11, 1-14. [CrossRef]

76. Varni, J.W. Pediatric Quality of Life Inventory TM. Available online: https://www.pedsql.org/ (accessed on 13 November 2020).

77. Ravens-Sieberer, U.; Erhart, M.; Rajmil, L.; Herdman, M.; Auquier, P.; Bruil, J.; Power, M.; Duer, W.; Abel, T.; Czemy, L.; et al. Reliability, construct and criterion validity of the KIDSCREEN-10 score: A short measure for children and adolescents' well-being and health-related quality of life. Qual. Life Res. 2010, 19, 1487-1500. [CrossRef]

78. Higuita-Gutiérrez, L.F.; Cardona-Arias, J.A. Instrumentos de evaluación de la calidad de vida relacionada con la salud del adolescente. Hacia Promocíon Salud 2020, 20, 27-42. [CrossRef]

79. CHQ, H.A. CHQ: Child Health Questionnaire 2019. Available online: https://www.healthactchq.com/survey/ chq (accessed on 13 November 2020).

80. Cantril, G. The Pattern of Human Concerns; Rutgers University Press: New Brunswick, NJ, USA, 1965.

81. Moreno, C.; Rivera, F.; García-moya, I.; Jiménez-iglesias, A.; Morgan, A. Cuestionario HBSC 2014—España; Estudio HBSC España: Sevilla, Spain, 2014; 52p.

82. Kline, T.J. Psychological Testing: A practical Approach to Design and Evaluation.; Sage Publications: Thousand Oaks, CA, USA, 2005.

83. Hu, L.; Bentler, P.M. Cutoff criteria for fit indexes in covariance structure analysis: Conventional criteria versus new alternatives. Struct. Equ. Model. 1999, 6, 1-55. [CrossRef]

84. Lopera-Vásquez, J. Calidad de vida relacionada con la salud: Exclusión de la subjetividad. Ciência Saúde Coletiva 2020, 25, 693-702. [CrossRef] [PubMed]

Publisher's Note: MDPI stays neutral with regard to jurisdictional claims in published maps and institutional affiliations.

(C) 2020 by the authors. Licensee MDPI, Basel, Switzerland. This article is an open access article distributed under the terms and conditions of the Creative Commons Attribution (CC BY) license (http://creativecommons.org/licenses/by/4.0/). 